\title{
ANTIOXIDANT ACTIVITY OF ETHYL ACETATE FRACTION OF MACARANGA TRILOBA LEAVES FROM CENTRAL KALIMANTAN
}

\author{
SYAHRIDA DIAN ARDHANY ${ }^{1 *}$, DEWI SARI MULIA ${ }^{1}$, PIENYANI ROSAWANTI² \\ ${ }^{1}$ Department of Health Science, Muhammadiyah University of Palangkaraya, Central Kalimantan, Indonesia. ${ }^{2}$ Department of Agriculture \\ and Forestry, Muhammadiyah University of Palangkaraya, Central Kalimantan, Indonesia. Email: chass501@gmail.com
}

Received: 25 February 2018, Revised and Accepted: : 01 March 2018

\section{ABSTRACT}

Objective: Macaranga triloba was used by the local for diabetes, antidiabetes have strong relation with antioxidant activity, antioxidants have been shown to prevent the destruction of $\beta$-cells by inhibiting the preoxidation chain reaction, plants containing natural antioxidant (like flavonoid and alkaloid) can protect $\beta$ cell function. So the objective of this study is to investigate antioxidant activity of ethyl acetate fraction of Macaranga triloba leaves and did preliminary phytochemical screening (Alkaloid and Flavonoid).

Methods: Macaranga triloba leaves (Mahang damar) were collected from the local areas of Bukit Rawi Central Kalimantan. Macaranga triloba leaves were extracted using maceration methods, followed by fractionation using liquid-liquid extraction methods starting from n-hexane, ethyl acetate, methanol but in this research used ethyl acetate fraction of Macaraga triloba and preliminary phytochemical screening for alkaloid used dragendorff and flavonoid used Pb Acetate. Antioxidant activity test was carried out using 1,1-diphenyl-2-pikrilhidrazil (DPPH) with quercetin as a reference.

Results: It was found that ethyl acetate fraction of Macaranga triloba leaves containing positive flavonoid that has been shown by dragendorff methode (brick red sedimen) and positive alkaloid by $\mathrm{Pb}$ acetate. The inhibition concentration $50\left(\mathrm{IC}_{50}\right)$ value of ethyl acetate fraction of Macaranga triloba leaves is $56.93 \mathrm{ppm}$

Conclusion: Macaranga triloba leaves by preliminary screening of phytochemical containing alkaloid and flavonoid. Antioxidant activity of ethyl acetate fraction with $\mathrm{IC}_{50}=56.93 \mathrm{ppm}$ is weaker than quercetin $\left(\mathrm{IC}_{50}=4.46 \mathrm{ppm}\right)$, but still in range value of strong antioxidant activity ( $\left.50-100 \mathrm{ppm}\right)$

Keywords: Antioxidant, Central Kalimantan, Macaranga triloba leaves, Quercetin, 1,1-diphenyl-2-pikrilhidrazil (DPPH).

(C) 2018 The Authors. Published by Innovare Academic Sciences Pvt Ltd. This is an open access article under the CC BY license (http://creativecommons. org/licenses/by/4. 0/) DOI: http://dx.doi.org/10.22159/ajpcr.2018.v11s3.30026

\section{INTRODUCTION}

Antioxidants play an important role a health-protecting factor. Antioxidants are compounds that have the ability to protect cells and tissues from damage caused by the threat of the presence of free radicals that are reactive [1]. At a time, one antioxidant molecule can react with single free radicals and is capable to neutralize free radicals by donating one of their own electrons, ending the carbon-stealing reaction. Cells produce defense against excessive free radicals by their preventative mechanisms, repair mechanisms, physical defenses, and antioxidant defenses. Antioxidants cause protective effects by neutralizing free radicals which are toxic byproducts of natural cell metabolism [2].

Many plants contain antioxidant compounds; epidemiological studies indicated the relationship between the plant antioxidants and reduction of chronic diseases. Antioxidant phytochemicals can be found in many foods and medicinal plants and play an important role in the prevention and treatment of chronic diseases caused by oxidative stress. They often possess strong antioxidant and free radical scavenging abilities, as well as anti-inflammatory action, which are also the basis of other bioactivities and health benefits such as anticancer, antiaging, and protective action for cardiovascular diseases, diabetes mellitus, obesity, and neurodegenerative diseases $[3,4]$.

Macaranga is one of the largest genera of the family Euphorbiaceae, comprising about 300 species. In addition to, in Indonesia found in parts of Africa, Madagascar, Asia, the east coast of Australia, and the Pacific islands [5]. Mahang damar (Macaranga triloba) leaves are one of the plants known by the people of Central Kalimantan as a medicinal plant for diabetes. Based on literature review, Macaranga species has long been used traditional medicine system such as Macaranga gigantea and M. triloba used to treat fungal infections and leaf decoction, stomachaches, and potential as an antioxidant $[5,6]$. Otherwise, Macaranga hypoleuca can be used a febrifuge, expectorant, and antispasmodic and also has potential as an antioxidant, antibacterial, and antidiabetic [7]. The objective of this research was to evaluate the antioxidant activity of ethyl acetate fraction M. triloba leaves in Central Kalimantan by 1,1-diphenyl-2-picrylhydrazyl (DPPH) scavenging method.

\section{METHODS}

\section{Preparation of extract}

M. triloba leaves (Mahang damar) were collected from the local areas of Bukit Rawi, Central Kalimantan. The part used in this study is the leaves that have been dried in direct sunlight after going through the process of weighing, sorting, and washing.

\section{Extraction}

Dried leaves of this plant were pulverized and about $50 \mathrm{~g}$ of powdered leaves were extracted with increasing order of polarity solvents series starting from n-hexane, ethyl acetate, and methanol by maceration. At last, all extracts were concentrated in a rotary evaporator. In this research used ethyl acetate fraction.

\section{Phytochemicals screening results}

Phytochemical screening was conducted on a sample M. triloba to determine the content of secondary metabolites which includes identification of alkaloids and identification flavonoids. 
Evaluation of antioxidant activity by DPPH radical scavenging method

Free radical scavenging activity of ethyl acetate fraction $M$. triloba leaves was measured by DPPH. In brief, $0.4 \mathrm{mM}$ solution of DPPH was prepared. This solution $(1 \mathrm{ml})$ was added to $4 \mathrm{ml}$ of ethyl acetate fraction at different concentrations $(20,40,60$, and $80 \mathrm{ppm})$. The mixture was shaken vigorously and allowed to stand at room temperature for $30 \mathrm{~min}$. Then, absorbance was measured at $516 \mathrm{~nm}$ using spectrophotometer (ultraviolet (UV)-Vis, Shimadzu). Reference standard compound being used was quercetin and experiment was done in duplicate. The inhibition concentration $50\left(\mathrm{IC}_{50}\right)$ of the sample, which is the concentration of sample required to inhibit $50 \%$ of the DPPH free radical, was calculated using log dose inhibition curve. A lower absorbance of the reaction mixture indicated higher free radical activity [8]. The percent DPPH scavenging effect was calculated using following equation:

DPPH scavenging effect $(\%)$ or percent inhibition $=\left(A_{0}-A_{1}\right) / A_{0} \times 100$

Where, $A_{0}$ was the absorbance of control reaction and $A_{1}$ was the absorbance in the presence of test or standard sample.

\section{RESULTS AND DISCUSSION}

\section{Phytochemical screening}

Many natural herbs contain antioxidant compounds which protect the cell against the damaging effects of ROS. Although our body is safeguarded by the natural antioxidant defense, there is always a demand for antioxidants from external natural source. In addition, secondary metabolites such as phenolic compounds, flavonoids, alkaloid, and tannins are widely distributed in plants and are reported to exert multiple biological effects including antioxidant, free radical scavenging abilities, anti-inflammatory, and anticarcinogenic [9].

Phytochemical analyze of ethyl acetate fraction of M. triloba leaves revealed the presence of alkaloid and flavonoid. Most recent researches have focused on the health aspects of flavonoids for humans. Many flavonoids are shown to have antioxidative activity, free radical scavenging capacity, coronary heart disease prevention, hepatoprotective, anti-inflammatory, and anticancer activities, while some flavonoids exhibit potential antiviral activities. In plant systems, flavonoids help in combating oxidative stress and act as growth regulators [10]. Flavonoids have been shown to be highly effective scavengers of the most oxidizing molecules including singlet oxygen and various free radicals implicated in several diseases [11-13]. The present study reports the in vitro antioxidant and antidiabetic activities of the major alkaloids isolated from Catharanthus roseus (Table 1) [14].

\section{Screening for antioxidant activity by DPPH method}

DPPH is stable nitrogen-centered free radical and has been extensively used to characterize an antioxidant. The reduction of DPPH radical serves as a quick and simple method to detect the antioxidant potential of compounds, especially those with phenol group. It is known that DPPH reacts rapidly with a compound containing weak $\mathrm{N}-\mathrm{H}$ or $\mathrm{O}-\mathrm{H}$ bonds. Electron transport is also an important mechanism for its reduction. It is reversible, reduced and due to its unpaired electron, densely colored. This property makes it suitable for spectrophotometric studies [15]

The principle of this antioxidant activity test method is to the measurement of the quantitative antioxidant activity by the measurement of DPPH radical scavenging by a compound having antioxidant activity using UV-Vis spectrophotometry so that it will be known that the value of free radical scavenging activity is expressed by $\mathrm{IC}_{50}$ value. $\mathrm{IC}_{50}$ value of $M$. triloba leaves obtained from the calculation of the linear regression equation which is done in two replication (duplicate) (Fig. 1)
Table 1: Result of chemical test of ethyl acetate fraction of M. triloba leaves

\begin{tabular}{lcc}
\hline Sample & Flavonoid & Alkaloid \\
\hline Ethyl acetate fraction of M. triloba & + & + \\
\hline
\end{tabular}

M. triloba: Macaranga triloba

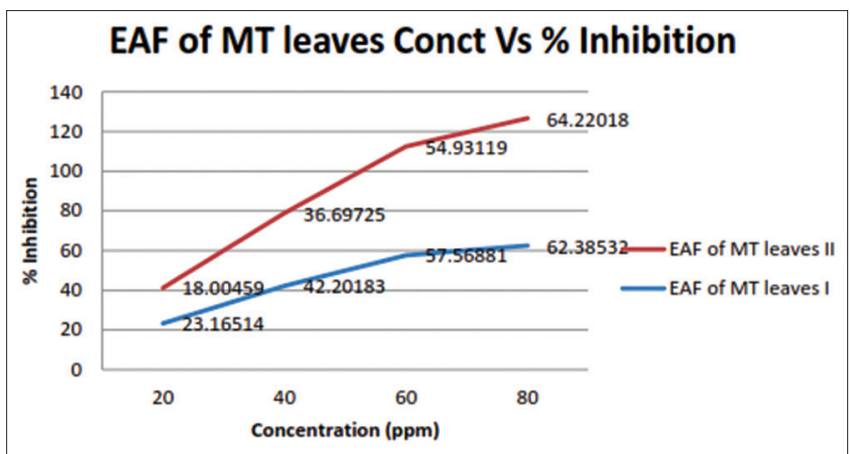

Fig. 1: Screening for 1,1-diphenyl-2-picrylhydrazyl scavenging effect of Macaranga triloba leaves

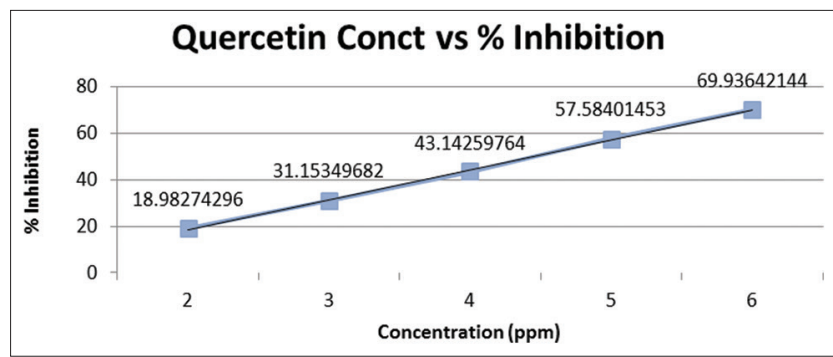

Fig. 2: Screening for 1,1-diphenyl-2-picrylhydrazyl scavenging effect of quercetin

Linear regression of ethyl acetate fraction of $M$. triloba leaves is $\mathrm{y}=0.6651 \mathrm{x}+13.073(\mathrm{r}=0.9714)$ for EAF of MT leaves I with $\mathrm{IC}_{50} 55.52 \mathrm{ppm}$ and $\mathrm{y}=0.7844 \mathrm{x}+4.2431(\mathrm{r}=0.9897)$ for EAF of MT leaves II with $\mathrm{IC}_{50} 58.33 \mathrm{ppm}$. IC I0 $_{50}$ value average of ethyl acetate fraction of $M$. triloba leaves is $56.93 \mathrm{ppm}$. A positive control was used in this study quercetin with $\mathrm{IC}_{50} 4.46 \mathrm{ppm}$ more than ethyl acetate fraction of M. triloba leaves. Used of positive controls on this antioxidant activity test to determine the antioxidant potential present in ethyl acetate fraction of $M$. triloba leaves when compared with quercetin. If the $\mathrm{IC}_{50}$ value of the sample is equal to near the $\mathrm{IC}_{50}$ value of positive control, it can be said that the sample has potential as one of the most powerful antioxidant alternatives.

Antioxidant activity of ethyl acetate fraction of $M$. triloba leaves $\left(\mathrm{IC}_{50}=56.93 \mathrm{ppm}\right)$ is lower than quercetin $\left(\mathrm{IC}_{50}=4.46 \mathrm{ppm}\right)$ but still has potential as an antioxidant. A substance has potent antioxidant activity when the $\mathrm{IC}_{50}$ value ranging between 50 and $100 \mathrm{ppm}$, where the substance has potential as antioxidants (Fig. 2) [16].

\section{CONCLUSION}

Based on this research, it is known that ethyl acetate fraction of M. triloba leaves has antioxidant activity with the ability to neutralize free radicals DPPH. Antioxidant activity of M. triloba leaves is shown by ethyl acetate fraction with the $\mathrm{IC}_{50}$ value of $56.93 \mathrm{ppm}$ while quercetin has $\mathrm{IC}_{50}=4.46 \mathrm{ppm}$ (very strong), but the $\mathrm{IC}_{50}$ value of ethyl acetate fraction of $M$. triloba leaves still in range value of strong antioxidant activity (50-100 ppm). Further, research is needed to test the antioxidant activity of $M$. triloba leaves using other methods. 


\section{REFERENCES}

1. Mustarichie R, Sandra M, Wiwiek I, Ade Z. Antioxidant activity of tauco extract and its fractions. Asian J Pharm Clin Res 2017;2017:57-61.

2. Bharti R, Gunja A, Ganapathy PS, Shruthi SD. A review on medicinal plants having antioxidant potential. J Pharm Res 2012;5:4278-87.

3. Zhang YJ, Gan RY, Sha Li, Zhou Y, Li AN, Xu DP, et al. Review antioxidant phytochemicals for the prevention and treatment of chronic diseases. MDPI Molecules J 2015;20:21138-56.

4. Sas K, Robotka H, Toldi J, Vecsei L, Mitochondrial, metabolic disturbances, oxidative stress, and kynurenine system, with focus on neurodegenerative disorders. J Neural Sci 2007;257:221-39.

5. Aminah NS, Alfinda NK, Mulyadi T. Antioxidant activity of flavonoid compounds from the leaves of Macaranga gigantean. J Chem Pharm Res 2014;6:688-92.

6. Lim TY, Lim YY, Yule CM. Bioactivity of leaves of Macaranga species in tropical peta swamp and non peta swamp environments. J Trop For Sci 2014;26:134-41.

7. Puteri MD, Kawabata J. Novel $\alpha$ glucosidase inhibitors from Macaranga tanarius Leaves. Food Chem 2010;123:384-9.

8. Shekar TC, Anju G. Antioxidant activity by DPPH radical scavenging method of Ageratum conyzoides Linn. Leaves. Am J Ethnomed 2014;1:244-9.
9. Nithya TG, Jayanthi J, Ragunathan MG. Antioxidant activity, total phenol, flavonoid, alkaloid, tannin and saponin contents of leaf extracts of Salvinia molesta. Asian J Pharm Clin Res 2016;9:200-3.

10. Kumar S, Pandey AK. Chemistry and biological activities of flavonoids: An overview. Sci World J 2013;2013:162750.

11. Jebbita SR, Jeyanth AS. Antioxidant activity, total phenol, flavonoid and anthocyanin contents of jamun (Syzygium cumini) pulp powder. Asian J Pharm Clin Res 2016;9:361-3.

12. Goveas SW, Asha A. Evaluation of antimicrobial and antioxidant activity of stem and leaf extracts of Coscinium fenestratum. Asian J Pharm Clin Res 2013;6:218-21.

13. Sowndhararajan K, Sun CK. Free radical scavenging activity from different extracts of leaves of Bauhinia vahlii Wight and Arn. Saudi J Bio Sci 2013;20:319-25.

14. Tiong SH, Chung YL, Hazrina H, Aditya A, Mohammadjavad P, Won FW, et al. Antidiabetic and antioxidant properties of alkaloids from Catharantus roseus (L.) G.Don. Molecules J 2013;18:9770-84.

15. Usmani SA. Screening for antioxidant and free radical scavenging potential of extracts of leaves and flowers of Calotropis gigantea. Asian J Pharm Clin Res 2013;6:97-100.

16. Molineux P. The use of the stable free radical diphenyl picrylhydrazil (DPPH) for estimating antioxidant activity. Songklankarin J Sci Technol 2004;26:211-9. 